\title{
Specification Bias in Contingent Valuation from Omission of Relative Price Variables*
}

\author{
JOHN C. WHITEHEAD \\ East Carolina University \\ Greenville, North Carolina \\ THOMAS J. HOBAN \\ WILLIAM B. CLIFFORD \\ North Carolina State University \\ Raleigh, North Carolina
}

\section{Introduction}

Little empirical research has been conducted on econometric specification issues in contingent valuation even though it is well known that specification error will result in biased coefficient estimates [17] and specification issues have been explored in the travel cost nonmarket valuation literature $[1 ; 22]$. In contingent valuation specification error may bias benefit estimates and estimated relationships between covariates and willingness to pay (WTP). McConnell [19] emphasizes the importance of specification in contingent valuation by determining appropriate empirical specifications and expected effects of exogenous variables such as own-prices and income. Also, Smith $[26,17]$ examines some recent empirical research focusing on potential errors due to omission of relative price variables.

Previous contingent valuation research has emphasized the inclusion of measures of ability to pay in WTP specifications [9]. What has been missing in WTP specifications is the inclusion of own-price and cross-price measures. Measures of relative prices are the travel and time costs of access to the natural resource being valued and any substitute or complementary natural resources. Related research has included proxies for relative price variables in WTP equations. Whitehead [30] finds that travel costs, with time valued at zero, has no effect on WTP. Sutherland and Walsh [28] and Silberman, Gerlowski, and Williams [24] find that distance, as a proxy for travel and time costs, has a negative effect on WTP. Whitehead and Blomquist [31], Boyle, Reiling, and Philips [6], Samples and Hollyer [23], and Silberman, Gerlowski, and Williams [24] use dummy variables to control for information and use about related natural resources and find mixed results.

\footnotetext{
*The research on which this paper is based was financed in part by the United States Environmental Protection Agency and the North Carolina Department of Environment, Health, and Natural Resources, through the AlbemarlePamlico Estuarine Study. Contents of this paper do not necessarily reflect the views and policies of the U.S. EPA or the N.C. DEHNR, nor does mention of trade names or commercial products constitute their endorsement by the U.S. or N.C. Government. The research reported in this publication was funded (in part) by the North Carolina Agricultural Research Service and by an East Carolina University Faculty Senate Summer Research Grant. The authors would like to thank Pete Groothuis and Tim Stanton for valuable comments on an earlier version of this paper. Any errors that remain are the authors' alone.
} 
Failure to include relative price measures can lead to omitted variable bias in two ways. First, coefficient estimates for omitted variables will not be found. Lack of estimates of own-price and cross-price effects can have important policy implications, such as mis-specification of the natural resources's market area. Second, coefficient estimates of included variables will be biased if omitted and included variables are correlated. The second type of bias could also have policy implications. For instance, if income is a determinant of WTP and population income is expected to increase in the future, biased income coefficients could lead to biased WTP forecasts.

In this paper we examine the potential for omitted variable bias in WTP for quality changes. We extend the theory of McConnell [19] and analyze the effects of changes in own-price and cross-prices on WTP for quality changes. This information allows prediction of omitted variable bias in the unestimated omitted variable coefficients. Also, this information, combined with expected correlations of omitted and included variables, allows predictions of the omitted variable bias in coefficients of included variables. We then address omitted variable bias by including measures of own-price and cross-price in an empirical WTP function for improvements in water quality and wildlife habitat in the Albemarle-Pamlico (A-P) estuarine system in North Carolina.' Omitted variable bias is assessed through signs, sizes, and significance levels of estimated relative price coefficients and changes in estimated income coefficients.

\section{Bias from Omission of Relative Price Variables}

Assume individuals have the utility function $u(\mathbf{x}, \mathbf{q}, Z)$, where $\mathbf{x}$ is a vector of demands for onsite use of natural resources, $\mathbf{q}$ is a vector of natural resource quality, and $Z$ is a composite of all market goods. The expenditure function, $e(\mathbf{p}, \mathbf{q}, u)$, is found by solving the consumer problem: minimize $Z+\mathbf{p}^{\prime} \mathbf{x}$ subject to $u=u(\mathbf{x}, \mathbf{q}, Z)$ where $\mathbf{p}$ is a vector of access prices for on-site use of natural resources and assuming the price of $Z$ is equal to $\$ 1$. The expenditure function measures the minimum amount of money a consumer must spend to achieve a fixed utility level and is increasing in $\mathbf{p}$ and $u$ and decreasing in $\mathbf{q}$.

Willingness to pay is the maximum amount of money respondents would give up in order to enjoy an environmental quality change. For simplicity, consider the case of two natural resources, $q_{1}$ being the A-P estuarine system and $q_{2}$ a related natural resource, such as the Chesapeake Bay, with all other resources suppressed. A formal definition of willingness to pay is

$$
W T P_{1}=e\left(p_{1}, p_{2}, q_{1}^{0}, q_{2}, u\right)-e\left(p_{1}, p_{2}, q_{1}^{\prime}, q_{2}, u\right)
$$

where $q_{1}^{0}$ is the current (degraded) level of quality and $q_{1}^{\prime}$ is an improvement in quality. Expenditures to maintain the utility level decrease with an increase in environmental quality $\left(q_{1}^{0}\right.$ to $\left.q_{1}^{\prime}\right)$ so that $W T P_{1} \geq 0$. In this framework, $W T P_{1}$ is a Hicksian measure of economic welfare [2] and includes use and nonuse values [25].

Assume households perceive the improved level of environmental quality as the level of quality to which they are entitled. The reference level of utility is $u=v\left(p_{1}, p_{2}, q_{1}^{\prime}, q_{2}, y\right)$, where $y$ is income and $v(\cdot)$ is the indirect utility function found by solving the problem: maximize $u(\cdot)$ subject to $y=Z+\mathbf{p}^{\prime} \mathbf{x}$. Substitution of the indirect utility function into equation (1) yields

1. The Albemarle-Pamlico estuarine system includes the Albemarle and Pamlico Sounds and rivers that flow into these sounds including the Chowan, Roanoke, Neuse, Tar, Alligator, and Pamlico Rivers in Eastern North Carolina. 


$$
W T P_{1}=e\left(p_{1}, p_{2}, q_{1}^{0}, q_{2}, v\left(p_{1}, p_{2}, q_{1}^{\prime}, q_{2}, y\right)\right)-y .
$$

Simplification of equation (2) yields the theoretical valuation function

$$
W T P_{1}=f\left(p_{1}, p_{2}, q_{1}^{0}, q_{1}^{\prime}, q_{2}, y\right) .
$$

The empirical valuation function is stochastic and contains a deterministic portion, which is the theoretical valuation function, and a random element

$$
W T P_{1}=f\left(p_{1}, p_{2}, q_{1}^{0}, q_{1}^{\prime}, q_{2}, y ; \tau\right)+\mu
$$

where $\tau$ is a vector of taste and preference variables included to reduce unexplained variation in $W T P_{1}$ and $\mu$ is a mean zero error term. Willingness to pay depends on relative prices, changes in quality, quality levels of related natural resources, income, and tastes.

To illustrate the potential for omitted variable bias, consider a simple regression equation which only includes relative price variables and income. In general, the sign of the bias in an included variable regression coefficient will be equal to the sign of the omitted variable regression coefficient multiplied by the sign of the correlation between the included and omitted variables. For example, the sign of the expected bias in the coefficient on income from omission of own-price or cross-price variables will be

$$
\operatorname{Sign}[\operatorname{bias} \text { in } \alpha]=\operatorname{Sign}\left[\beta_{i}\right] \cdot \operatorname{Sign}\left[r\left(p_{i}, y\right)\right]
$$

where $\alpha$ is the regression coefficient on income, $r\left(p_{i}, y\right)$ is the correlation coefficient between price and income, $i=1,2, \boldsymbol{\beta}_{1(2)}$ is the coefficient on own- (cross-) price. We consider two cases of bias in included variables. The first is the bias in the income coefficient from sequential omission of the own-price and cross-price variables. Second, we consider the bias in the own-price coefficient from omission of a relevant cross-price term. To determine the expected bias we must first determine the expected effects of exogenous variables on $W T P_{1}$ and expected correlations between variables. ${ }^{2}$

The effect of own-price of on-site use on $W T P_{1}$ is $\partial W T P_{1} / \partial p_{1}<0 . W T P_{1}$ increases (decreases) with decreases (increases) in the own-price of on-site use since recreation demand is higher with higher natural resource quality. The cross-price effect is $\partial W T P_{1} / \partial p_{2} \gtrless 0$. If $q_{1}$ and $q_{2}$ are substitutes then the cross-price effect is positive since increases in the quality of resource 1 will increase the demand for trips to resource 1 and decrease the demand for trips to resource 2 . If $q_{1}$ and $q_{2}$ are complements then the cross-price effect is negative since increases in the quality of resource 1 will increase the demand for trips to resource 1 and resource 2. The effect of income on $W T P_{1}$ for quality improvement is $\partial W T P_{1} / \partial y>0$. Willingness to pay for quality is increasing in income if quality is a normal good.

The expected sign of the correlation coefficient between own-price and cross-price and relative prices and income can be determined after construction of price variables and the spatial relationship between households and natural resources is clarified. The basic insight of the recreation demand literature is that the quantity of recreation trips demanded (on-site use) varies

2. To derive these results we assume that quality is a normal good and quality and recreation trips are Hicks complements. A mathematical appendix to this paper, which includes derivation of comparative static results, can be obtained from the authors. 
Table I. Effects of Relative Price Variable Omission on Income Coefficients

\begin{tabular}{ccccc}
\hline & \multicolumn{3}{c}{ Bias in $\alpha$} \\
\cline { 3 - 5 } Time Costs & $\operatorname{Sign}\left[r\left(p_{i}, y\right)\right]$ & $\frac{\beta^{2} \text {-Price }}{\beta_{1}<0}$ & & \multicolumn{2}{c}{ Cross-Price } \\
\hline$\delta=0$ & $?$ & $?$ & $?$ & $\beta_{2}<0$ \\
$\delta>0$ & + & - & + & - \\
\hline
\end{tabular}

inversely with the price of the trip. The price of on-site use of a natural resource is the travel and time costs of access. The typical construction of the price variable is

$$
p_{i}=c_{d} \cdot d_{i}+\delta w_{j} \cdot\left(d_{i} / m p h_{i j}\right)
$$

where $c_{d}$ is the travel cost per mile, $d_{i}$ is the round trip distance to the $i$ th site, $w_{j}$ is the wage rate of the $j$ th household, $0 \leq \delta \leq 1$, and $m p h_{i j}$ is miles per hour of the $j$ th household to the $i$ th site. ${ }^{3}$ Travel costs per mile and miles per hour are usually assumed to be constant. Variations in the price of a trip are due only to variations in distance, the wage rate, and the opportunity cost of time.

Assuming that distance to natural resource sites and household income are uncorrelated, if the opportunity cost of time is assumed zero, the expected correlation can not be signed. If the opportunity cost of time is assumed positive and since the wage rate is proportional to income, relative prices will be positively correlated with income.

The correlation of own-price and cross-price depends on the location of households relative to the location of natural resource sites [8]. If the related natural resources lie in the same direction from the relevant population then the correlation between distance traveled and prices will be positive. If the related natural resources lie in opposite directions from the relevant population then the correlation between distance traveled and prices will be negative. ${ }^{4}$

Table I summarizes the expected bias on the income coefficient from omission of relative prices. If time costs are assumed zero, no expectations about the sign of the bias in the income coefficient can be made. If time costs are assumed positive, the sign of the bias on the income coefficient will depend on the sign of the coefficient on the relative price variables. Omission of the own-price variable will negatively bias the income coefficient since the expected sign of own-price is negative. Omission of the cross-price variable could positively or negatively bias the

3. Our construction of the opportunity cost of time makes one of three implicit simplifying assumptions about labor supply depending on the value assigned to $\delta$. If $\delta=1$, this implies that households can freely choose the number of hours worked. If $0<\delta<1$, this implies that households are constrained to work a fixed number of hours at their primary job but can freely choose the number of hours to work at a secondary job. If $\delta=0$, this implies that no secondary job is available and the opportunity cost of time is zero. Since time is a scarce commodity, the third assumption underestimates the trip price. In empirical applications McConnell and Strand [20] estimate the opportunity cost of time at $60 \%$ of the wage rate. Smith, Desvousges, and McGivney [27] are unable to statistically choose between opportunity costs equal to one-third of the wage rate and the full wage rate. Bockstael, Strand, and Hanemann [4] find that for people who have flexible work hours the opportunity cost of time is equal to the wage rate and for people with constrained work hours the opportunity cost of time is greater than the wage rate. See Bockstael, Strand, and Hanemann [4] for discussion of issues regarding the appropriate measure of the opportunity cost of time.

4. Caulkins, Bishop, and Bouwes [8] give the example of two lakes lying north and south. If population centers lie to the east or west the correlation between travel distances to the two lakes will be positive. If population centers lie on a line running north and south the correlation between travel distances will be negative. 
Table II. Effects of Cross-Price Variable Omission on Own-Price Coefficients

\begin{tabular}{ccc}
\hline & \multicolumn{3}{c}{ Bias in $\beta_{1}$} \\
\cline { 2 - 3 } $\operatorname{Sign}\left[r\left(p_{1}, p_{2}\right)\right]$ & $\beta_{2}>0$ & $\beta_{2}<0$ \\
\hline+ & + & - \\
- & - & + \\
\hline
\end{tabular}

income coefficient depending on the relationship between the natural resources in consumption. If the natural resources are substitutes (complements) the income coefficient will be positively (negatively) biased. The sign of the bias on the income coefficient from omitting both the ownprice and cross-price variables could be positive or negative depending on the relative sizes of bias from individual omissions.

Table II summarizes the expected bias in the own-price coefficient from omission of the cross-price variable. The bias will be positive for substitute resources which lie in the same direction and for complementary resources which lie in the opposite direction. The second case is unlikely if complementary natural resources are defined as those natural resources that generate multi-destination trips [12]. A multi-destination trip in opposite directions would be inefficient since travel plans would involve backtracking. The bias in the own-price coefficient will be negative for substitute resources which lie in the opposite direction and for complementary resources which lie in the same direction. The second case here is likely since complementary resources will generate multi-destination trips which are efficient for households to plan when the resources are in the same direction.

\section{Data Collection}

The 1991 A-P Estuarine Study telephone survey was conducted with a primary purpose of gathering WTP data for a program to manage A-P system resources [15].

\section{Contingent Market Design}

The contingent valuation question in the $1991 \mathrm{~A}-\mathrm{P}$ estuarine system household survey was in the form of an iterative political market $[16 ; 21]$ which presented survey respondents with a hypothetical referendum vote: "Would you and your household be willing to pay \$A each year in higher taxes, . . . if you knew the money would be used to protect the A-P system?" The starting point tax amount ( $\$ A)$ took on twelve values with a random start ranging from $\$ 5$ to $\$ 100(5,10,15$, $20,30,40,50,60,70,80,90$, and 100). The range of starting points was pretested in Hoban and Clifford [14]. Respondents answer "yes" to the policy referendum valuation question if the individual benefit of the policy (WTP to gain the environmental quality change) is greater than the individual cost of the policy (the tax payment \$A). Respondents answer "no" if the individual benefit of the policy is less than the individual cost of the policy.

Once initial yes or no responses are revealed, respondents were asked follow up questions to narrow the range of stated WTP. If the respondent answered yes, the valuation question was asked again with the next highest dollar amount. This process continued until the respondent answered no or $\$ 100$ was reached. If the respondent answered no, the valuation question was asked again with the next lowest dollar amount. This process continued until the respondent answered yes or 
$\$ 5$ was reached. For respondents reaching $\$ 5$ or $\$ 100$, the open ended question: "What is the most that you and your household would be willing to pay each year . . ?" is presented. Hoehn and Randall [16] show how this type of contingent market design will produce a WTP statement that does not overstate true WTP.

With open-ended WTP questions, WTP is explicitly revealed (e.g., a survey respondent may answer " $\$ 150$ " in response to this question). The iterative political market, while easier to answer, generates less information about WTP than open-ended WTP questions. The iterative form of the contingent market allows WTP to be bounded within a $\$ 5$ to $\$ 10$ range up to $\$ 100$. A point estimate of WTP is obtained for respondents with WTP greater than $\$ 100$.

\section{Survey Design}

The survey design employed was cross-sectional utilizing a random sample of households with telephones. The universe for the survey was defined as the 100 counties in North Carolina and the 16 counties/independent cities in Virginia within the watershed of the A-P estuarine system. We chose to use a disproportionate stratified random sample. The counties making up the universe were stratified into five standard geographic regions: Mountain (NC), Piedmont (NC), Coastal Plain (NC), Tidewater (NC), and Virginia. Phone numbers for the sample were selected using a random digit dialing technique.

A total of 1,133 interviews were completed: 211 in the Mountain region, 279 in the Piedmont, 236 in the Coastal Plain, 199 in the Tidewater, and 208 in Virginia. Repeated efforts were made to contact households to assure a representative sample. A minimum of twelve attempts were made before a number was eliminated from consideration. Attrition typically took the form of refusals or termination before interview completion. An overall completion rate of $70.5 \%$ was obtained.

\section{Data Summary}

In Tables III and IV we present descriptions, means, and standard deviations of variables used in the empirical analysis. The dependent variable in the empirical analysis is $W T P_{1}$. Independent variables are of four types. The first type is the tax variable, $\$ A$, which was randomly assigned to households. The second type are the variables derived from utility theory that are expected to affect $W T P_{1}$ : own-price, cross-price, and income. The third and fourth types of variables are elements of the $\tau$ vector in equation (4). The third type of variables are demographic characteristics such as education and age which may influence a respondent's $W T P_{1}$. Once sample data is weighted by the four North Carolina regions and one Virginia region, income and demographic characteristics are representative of the population [15]. The fourth type of variables are taste and preference variables which reflect perceptions of specific and general environmental problems and related behavior.

Willingness to pay is summarized by continuous and interval data. The continuous data is formed by using interval midpoints as proxy variables for the random $W T P_{1}$ within the intervals for $W T P_{1}$ less than $\$ 100$ (Table IV). The implicit assumption is that the best estimate of $W T P_{1}$ is the interval midpoint. For $W T P_{1}$ statements greater than $\$ 100$ the open-ended $W T P_{1}$ response is used as a point estimate of true $W T P_{1}$. Complete data for 1033 cases are available for analysis. ${ }^{5}$

5. One-hundred protest and outlying responses are deleted from the data. Protest WTP responses result when the survey respondent rejects the notion of valuing a non-market resource or the hypothetical market institution. Respondents may protest by answering $\$ 0, \$ 1,000,000$, or "priceless" in response to an open-ended valuation question when their true 
Table III. Description of Variables

\begin{tabular}{|c|c|}
\hline Variable & Description \\
\hline$W T P_{1}$ & $\begin{array}{l}\text { Iterated response to the question: "Would you and your household be willing to pay } \\
\text { \$A each year in higher taxes, for these programs, if you knew it would be used to } \\
\text { protect the A-P system?" }\end{array}$ \\
\hline $\operatorname{Tax}$ & The dollar value $(\$ \mathrm{~A})$ in the willingness to pay question. \\
\hline Own-Price & $\begin{array}{l}\text { The dollar and time costs of a trip to the Albemarle-Pamlico estuarine system }= \\
\$ .08 *(\text { round trip distance })+(\delta * \text { hourly wage }) *(\text { round trip distance } / 56.5 \mathrm{mph})\end{array}$ \\
\hline Cross-Price & $\begin{array}{l}\text { The dollar and time costs of a trip to the Chesapeake Bay }=\$ .08 *(\text { round trip distance }) \\
+(\delta * \text { hourly wage }) *(\text { round trip distance } / 56.5 \mathrm{mph})\end{array}$ \\
\hline Income & $\begin{array}{l}\text { Response to the question: "Which of the following categories best represents your } \\
\text { family's } 1990 \text { total income before taxes? Please include all income sources such as } \\
\text { wages, salaries, pension dividends, net farm income, and government payments." }\end{array}$ \\
\hline Education & Response to the question: "What is the highest grade of school you have completed?" \\
\hline Age & Ninety-one minus the response to the question: "In what year were you born?" \\
\hline Race & $\begin{array}{l}\text { Equal to } 0 \text { if respondent answers other than white to the question "Are you white, } \\
\text { black, American Indian, or some other race?" Equal to } 1 \text { if respondent is white. }\end{array}$ \\
\hline Gender & Equal to 0 if the respondent is male, 1 if the respondent is female. \\
\hline Property & $\begin{array}{l}\text { Equal to } 1 \text { if the respondent answers "yes" to the question: "Do you own or have part } \\
\text { ownership in any property at or near the coast?" Equal to } 0 \text { otherwise. }\end{array}$ \\
\hline Urban & $\begin{array}{l}\text { Equal to } 1 \text { if respondent answers "a city" to the question: "Is your home located in a } \\
\text { rural area, a small town, a suburb or a city?" Equal to } 0 \text { otherwise. }\end{array}$ \\
\hline Know & $\begin{array}{l}\text { Knowledge about the Albemarle-Pamlico estuarine system. Equal to } 4 \text { if "A Lot," to } \\
3 \text { if "Some," equal to } 2 \text { if "A Little," and } 1 \text { if "Nothing." }\end{array}$ \\
\hline Concern & $\begin{array}{l}\text { A scale variable from two questions covering concern about water pollution and } \\
\text { damage to fish and wildlife habitat in the A-P system. The scale variable increases } \\
\text { with more concern. }\end{array}$ \\
\hline Value & $\begin{array}{l}\text { Reasons for valuing rivers and sounds of the A-P system. The scale variable increases } \\
\text { as reasons increase in importance. }\end{array}$ \\
\hline Trust & $\begin{array}{l}\text { Scale variable which increases with trust in county, state, and Federal governmental } \\
\text { officials. }\end{array}$ \\
\hline Beliefs & $\begin{array}{l}\text { A weighted scale variable which increases with positive attitudes toward the } \\
\text { environment in general. }\end{array}$ \\
\hline Activism & $\begin{array}{l}\text { Scale variable which increases with activities related to positive attitudes toward the } \\
\text { environment. }\end{array}$ \\
\hline
\end{tabular}

The WTP interval data are summarized in Table V by frequency of the WTP response within each interval. For WTP statements greater than $\$ 100$ the frequency of the open-ended WTP re-

WTP is something else. It is common practice to identify protest responses by follow-up questions to the valuation question and delete the answers thought to be protests frorn contingent valuation data. This study identifies protest responses in two ways. For zero dollar respondents the follow-up question: "Why would you not be willing to pay anything?" is presented. Respondents who answer "polluters should pay", "can't put dollar value on resources" or "oppose this type of question" are considered to reject the contingent market institution. Respondents who answer "government not effective or corrupt" or "don"t trust" are felt to reject existing governmental institutions. These cases are deleted from the data. Other reasons, which reflect rejection of the payment vehicle (taxes), are "on fixed income," "A-P users should pay," "should be voluntary," and "need state lottery" and are also deleted. For respondents who give open-ended answers, outlying protest responses include those who answer "priceless" or "greater than $\$ 995$ " to the open-ended valuation question. 
Table IV. Data Summary

\begin{tabular}{lrc}
\hline Variable & Mean & Standard Deviation \\
\hline WTP $_{1}$ & $\$ 59.92$ & 64.86 \\
Tax & $\$ 46.90$ & 31.16 \\
Own-Price $^{\mathrm{a}}$ & $\$ 153.93$ & 68.65 \\
Cross-Price $^{\text {a }}$ & $\$ 185.34$ & 83.42 \\
Income $^{\text {b }}$ & $\$ 36.63$ & 29.35 \\
Education $_{\text {Age }}$ & 14.28 & 3.61 \\
Race & 45.34 & 15.80 \\
Gender & 0.81 & 0.39 \\
Property & 0.54 & 0.50 \\
Urban & 0.13 & 0.34 \\
Know & 0.25 & 0.43 \\
Concern & 2.32 & 0.95 \\
Value & 5.28 & 0.91 \\
Trust & 20.17 & 3.09 \\
Beliefs & 9.52 & 1.81 \\
Activism & 5.14 & 0.47 \\
\hline a Measured & 5.68 & 2.16 \\
\hline
\end{tabular}

a. Measured with the opportunity cost of time set at the wage rate in 1990 dollars.

b. Measured in thousands of 1990 dollars.

sponse is grouped by WTP point estimates into intervals. The assumption here is that the WTP point estimate indicates a likely range of WTP values. Twenty-one intervals are formed. The percentage responses in each range are less than $6 \%$ except for four intervals: $W T P_{1}=\$ 0-\$ 5$, $\$ 20-\$ 30, \$ 50-\$ 60$, and $\$ 100-\$ 125$. This result suggests that responses were anchored to familiar dollar values such as $\$ 5, \$ 25, \$ 50$, and $\$ 100$.

Construction of the own-price and cross-price variables are consistent with the recreation demand literature (equation 5). We use the Chesapeake Bay estuarine system as the potentially related natural resource due to its similarity of characteristics and services provided. ${ }^{6}$ Round trip distance to both the A-P system and the Chesapeake Bay are calculated as the driving distance from the population centers of the respondent's county to the nearest water access. ${ }^{\text {? }}$ Round trip driving distance is converted to round trip travel and time costs by valuing driving distance at $\$ .08$ per mile and driving time at $100 \%$ of the wage rate and setting average miles per hour to 56.5. ${ }^{8}$ Valuing time costs at the wage rate, the mean own-price is $\$ 154$ while the mean cross-price is $\$ 185$.

6. The Sounds associated with Hilton Head Island, South Carolina were also considered as a related natural resource. The Hilton Head cross-price variable captures the behavior of households in western North Carolina who frequently travel to South Carolina for outdoor recreation. In the regressions that follow, the Hilton Head cross-price variable was too collinear with income to allow useful interpretations of other utility-theoretic variables and was dropped from the analysis.

7. Several access points to the Albemarle-Pamlico estuarine system are used by recreationists. In this study, Edenton and Washington, NC were assumed primary access points to the system for respondents who live west of the sounds. Minimum driving distance was found to the two cities and summed for an estimate of round trip driving distance to the A$P$ system. For respondents who live east of Edenton and Washington, minimum driving distance was found to the nearest cities with boat access for both sounds and summed to get an estimate of round trip driving distance. Norfolk, Virginia was assumed the access point for the Chesapeake Bay.

8. Driving cost per mile and average miles per hour for North Carolina are found in the Statistical Abstract of the United States, 1991. 
Table V. WTP Frequencies

\begin{tabular}{ccc}
\hline WTP Interval & Frequency & Percent \\
\hline$\$ 0-5$ & 133 & 12.9 \\
$5-10$ & 48 & 4.6 \\
$10-15$ & 53 & 5.1 \\
$15-20$ & 57 & 5.5 \\
$20-30$ & 94 & 9.1 \\
$30-40$ & 61 & 5.9 \\
$40-50$ & 56 & 5.4 \\
$50-60$ & 11 & 10.7 \\
$60-70$ & 64 & 5.2 \\
$70-80$ & 46 & 4.5 \\
$80-90$ & 36 & 3.5 \\
$90-100$ & 35 & 3.4 \\
$100-125$ & 202 & 19.6 \\
$125-150$ & 1 & 0.1 \\
$150-200$ & 13 & 1.3 \\
$200-250$ & 17 & 1.6 \\
$250-300$ & 3 & 0.3 \\
$300-400$ & 4 & 0.4 \\
$400-500$ & 1 & 0.1 \\
$500-600$ & 5 & 0.5 \\
$600+$ & 3 & 0.3
\end{tabular}

\section{Results}

Omission of relative price variables leads to specification bias if the signs of own-price and crossprice variable coefficients are theoretically correct, and, if $t$-statistics on these variables indicate that they are statistically significant. Omitted variable bias may also occur if signs and significance levels of included variable coefficients change with inclusion of previously omitted variables.

We specify WTP to depend on relative prices and income, the starting tax payment, demographic variables, and preference variables. Using the midpoints of the WTP intervals as continuous data could lead to biased WTP and coefficient estimates since the midpoint of the interval is not necessarily the expected value of WTP within the interval [7]. Cameron and Huppert [7] suggest a maximum likelihood procedure for interval data which will generate unbiased estimates. ${ }^{9}$ Models are estimated with the grouped data regression procedure using the LIMDEP econometrics software [10]. The data is weighted by region to adjust for sample stratification [18].

\section{Testing for Omitted Variable Bias}

Of the three models estimated (Table VI), the first represents the type that is regularly presented by contingent valuation researchers including only income, demographic and preference variables while omitting relative price variables. With this data WTP increases at a decreasing rate with the

9. If the assumption that the midpoints of the WTP intervals are equal to true WTP within the intervals is true, Tobit is the appropriate econometric method [11]. In this study, empirical results using the Tobit technique are qualitatively similar to the grouped data regression. See Whitehead, Hoban, and Clifford [32] for this analysis. 
starting point tax amount. ${ }^{10}$ The positive sign on the income coefficient indicates that environmental quality in the A-P system is a normal good. Age and sex differences have significant effects on WTP. WTP decreases by $\$ .72$ for each additional year of age. Males are willing to pay $\$ 7.88$ more than females. Coefficients on the preference variables, Concern, Beliefs, and Activism, are statistically significant and have the expected signs."

In the second model the own-price variable is added. The own-price coefficient is of the correct sign and significantly different from zero at the $99 \%$ confidence level. This result is supported by the likelihood-ratio test. The significance of the likelihood-ratio statistic indicates that the own-price variable adds explanatory power to the model $\left(\chi^{2}[1]=8.8\right)$.

The correlation coefficient between the own-price coefficient and income is positive, high, and significantly different from zero. With opportunity costs of time valued at the wage rate the expected bias in the income coefficient is negative for omission of the own-price variable (Table I). The empirical result is that the coefficient on income increases by $44 \%$ with inclusion of the own-price variable.

In the third model the cross price variable is added. The sign of the cross-price coefficient is positive and significantly different from zero at the $95 \%$ confidence level. The significance of the chi-square statistic from the likelihood-ratio test indicates that the cross-price variable adds explanatory power to the model $\left(\chi^{2}[1]=8.2\right)$. This result indicates that the Chesapeake Bay is a substitute natural resource for A-P system resources. As the cost of on-site access to the Chesapeake Bay decreases (increases) WTP for environmental quality in the A-P system decreases (increases).

The correlation coefficient between the own-price variable and the cross-price variable is positive, high, and significantly different from zero. The expected bias for omission of a substitute natural resource located in the same direction from population centers is positive (Table II). As expected, the own-price coefficient falls by over $100 \%$ as the cross-price variable is added.

The correlation coefficient between the own-price variable and income is positive, high, and significantly different from zero. The expected bias in the income coefficient is positive for omission of the cross-price term (Table I). The empirical effect of adding the cross-price term is that the coefficient on income decreases by $4 \%$. Comparing Models 1 and 3, the effect of including the own-price variable outweighs the effect of including the cross-price variable. The income coefficient is downwardly biased by $40 \%$ when relative price variables are not included.

\section{Opportunity Cost of Time Sensitivity Analysis}

In Table VII we examine the sensitivity of the omitted variable bias results to the assumption on the opportunity cost of time. Of the five models presented in Table VII, two are repeated from Table VI for comparison. The first model omits relative price variables. The other four models in-

10. Starting point bias results when respondents consider the initial dollar amount offered as an implied "correct" WTP. Regressions of the form $W T P_{1}=\alpha+\tau A$ are typically used to test for starting point bias [5]. Starting points above (below) respondents' true WTP will increase (decrease) stated WTP. To adjust for starting point bias with this data, a conservative technique is implemented by Whitehead [29]. See also Whitehead, Hoban, and Clifford [32].

11. Willingness to pay is a statement of a behavioral intention [13]. Mitchell and Carson [21] and Bishop and Heberlein [3] discuss factors which determine whether the attitude-behavioral intention link can be used to predict actual behavior. Significant correlations between attitude and behavioral intention variables increase the chances that the intention will result in actual behavior. Evidence of social psychological theoretical validity, such as the statistical significance of Concern, Beliefs, and Activism, increases our confidence that the stated behavioral intention of WTP is a good predictor of actual behavior of households if they are placed in the payment situation. 
Table VI. Maximum Likelihood Interval Estimates

\begin{tabular}{|c|c|c|c|}
\hline Variable & Model 1 & Model 2 & Model 3 \\
\hline Intercept & $\begin{array}{c}-105.29 * * * \\
(-3.44)^{\mathrm{a}}\end{array}$ & $\begin{array}{c}-100.59 * * * \\
(-3.31)\end{array}$ & $\begin{array}{l}-96.71^{* * *} \\
(-3.16)\end{array}$ \\
\hline $\operatorname{Tax}$ & $\begin{array}{l}1.22 * * * \\
(4.50)\end{array}$ & $\begin{array}{l}1.22 * * * \\
(4.54)\end{array}$ & $\begin{array}{l}1.21 * * * \\
(4.50)\end{array}$ \\
\hline $\operatorname{Tax}{ }^{2}$ & $\begin{array}{l}-0.0051^{*} \\
(-1.94)\end{array}$ & $\begin{array}{l}-0.0051 * * \\
(-1.96)\end{array}$ & $\begin{array}{l}-0.0050^{*} \\
(-1.91)\end{array}$ \\
\hline Own-Price & - & $\begin{array}{l}-0.080^{* * *} \\
(-3.02)\end{array}$ & $\begin{array}{l}-0.17 * * * \\
(-3.33)\end{array}$ \\
\hline Cross-Price & - & 一 & $\begin{array}{l}0.080 * * \\
(2.03)\end{array}$ \\
\hline Income & $\begin{array}{l}0.51^{* * * *} \\
(6.43)\end{array}$ & $\begin{array}{l}0.79 * * * \\
(6.51)\end{array}$ & $\begin{array}{l}0.76^{* * *} \\
(6.23)\end{array}$ \\
\hline Education & $\begin{array}{c}0.84 \\
(1.23)\end{array}$ & $\begin{array}{c}0.84 \\
(1.25)\end{array}$ & $\begin{array}{c}0.87 \\
(1.29)\end{array}$ \\
\hline Age & $\begin{array}{l}-0.72 * * * \\
(-5.30)\end{array}$ & $\begin{array}{l}-0.69 * * * \\
(-5.03)\end{array}$ & $\begin{array}{l}-0.68 * * * \\
(-5.01)\end{array}$ \\
\hline Race & $\begin{array}{c}2.97 \\
(0.54)\end{array}$ & $\begin{array}{c}4.25 \\
(0.77)\end{array}$ & $\begin{array}{c}4.12 \\
(0.75)\end{array}$ \\
\hline $\operatorname{Sex}$ & $\begin{array}{c}-7.88^{*} \\
(-1.88)\end{array}$ & $\begin{array}{l}-8.25^{* *} \\
(-1.98)\end{array}$ & $\begin{array}{l}-8.31^{* *} \\
(-2.00)\end{array}$ \\
\hline Property & $\begin{array}{c}3.07 \\
(0.49)\end{array}$ & $\begin{array}{l}-0.059 \\
(-0.0094)\end{array}$ & $\begin{array}{c}0.61 \\
(0.097)\end{array}$ \\
\hline Urban & $\begin{array}{c}5.74 \\
(1.20)\end{array}$ & $\begin{array}{c}4.49 \\
(0.94)\end{array}$ & $\begin{array}{c}4.51 \\
(0.94)\end{array}$ \\
\hline Know & $\begin{array}{c}0.099 \\
(0.04)\end{array}$ & $\begin{array}{c}-1.25 \\
(-0.53)\end{array}$ & $\begin{array}{c}-1.79 \\
(-0.75)\end{array}$ \\
\hline Concern & $\begin{array}{l}7.29 * * * * \\
(2.72)\end{array}$ & $\begin{array}{l}7.26^{* * * *} \\
(2.73)\end{array}$ & $\begin{array}{l}7.01 * * * \\
(2.64)\end{array}$ \\
\hline Value & $\begin{array}{c}-1.07 \\
(-1.38)\end{array}$ & $\begin{array}{c}-1.22 \\
(-1.58)\end{array}$ & $\begin{array}{c}-1.26 \\
(-1.64)\end{array}$ \\
\hline Trust & $\begin{array}{c}-0.42 \\
(-0.36)\end{array}$ & $\begin{array}{c}-0.39 \\
(-0.34)\end{array}$ & $\begin{array}{c}-0.54 \\
(-0.46)\end{array}$ \\
\hline Beliefs & $\begin{array}{l}15.44^{* * * *} \\
(3.30)\end{array}$ & $\begin{array}{l}15.67 * * * \\
(3.36)\end{array}$ & $\begin{array}{l}15.60 * * * \\
(3.36)\end{array}$ \\
\hline Activism & $\begin{array}{l}5.71^{* * * *} \\
(5.00)\end{array}$ & $\begin{array}{l}5.78^{* * *} \\
(5.09)\end{array}$ & $\begin{array}{l}5.87 * * * \\
(5.18)\end{array}$ \\
\hline$\sigma$ & $\begin{array}{c}63.91 \\
(36.91)\end{array}$ & $\begin{array}{c}63.57 \\
(37.03)\end{array}$ & $\begin{array}{c}63.37 \\
(34.96)\end{array}$ \\
\hline Log-Likelihood & -2937.9 & -2933.5 & -2929.4 \\
\hline
\end{tabular}

a. $t$-statistic in parentheses.

$* * *, * *, *$ indicates significance at the $99 \%, 95 \%$, and $90 \%$ levels. 
Table VII. Maximum Likelihood Interval Estimates: Opportunity Cost of Time Sensitivity Analysis

\begin{tabular}{|c|c|c|c|c|c|}
\hline \multirow[b]{2}{*}{ Variable } & & \multicolumn{4}{|c|}{ Time Costs } \\
\hline & & $0 \%$ of wage & $33 \%$ of wage & $60 \%$ of wage & $100 \%$ of wage \\
\hline Intercept & $\begin{array}{c}-105.29 * * * \\
(-3.44)^{\mathrm{a}}\end{array}$ & $\begin{array}{l}-95.63 * * * \\
(-3.09)\end{array}$ & $\begin{array}{l}-94.92^{* * *} \\
(-3.10)\end{array}$ & $\begin{array}{l}-95.88^{* * *} \\
(-3.13)\end{array}$ & $\begin{array}{l}-96.71 * * * \\
(-3.16)\end{array}$ \\
\hline $\operatorname{Tax}$ & $\begin{array}{l}1.22 * * * \\
(4.50)\end{array}$ & $\begin{array}{l}1.21 * * * \\
(4.48)\end{array}$ & $\begin{array}{l}1.21^{* * *} \\
(4.49)\end{array}$ & $\begin{array}{l}1.21 * * * \\
(4.49)\end{array}$ & $\begin{array}{l}1.21 * * * \\
(4.50)\end{array}$ \\
\hline $\operatorname{Tax}^{2}$ & $\begin{array}{l}-0.0051 * * \\
(-1.94)\end{array}$ & $\begin{array}{l}-0.0050^{* *} \\
(-1.92)\end{array}$ & $\begin{array}{l}-0.0050 * * \\
(-1.91)\end{array}$ & $\begin{array}{l}-0.0050 * * \\
(-1.91)\end{array}$ & $\begin{array}{l}-0.0050^{* *} \\
(-1.91)\end{array}$ \\
\hline Own-Price & - & $\begin{array}{c}-0.52^{*} \\
(-1.79)\end{array}$ & $\begin{array}{l}-0.35^{* * *} \\
(-2.99)\end{array}$ & $\begin{array}{l}-0.24 * * * \\
(-3.20)\end{array}$ & $\begin{array}{l}-0.17 * * * \\
(-3.33)\end{array}$ \\
\hline Cross-Price & - & $\begin{array}{c}0.27 \\
(1.12)\end{array}$ & $\begin{array}{c}0.17^{*} \\
(1.83)\end{array}$ & $\begin{array}{r}0.12^{*} \\
(1.95)\end{array}$ & $\begin{array}{l}0.08^{* *} \\
(2.03)\end{array}$ \\
\hline Income & $\begin{array}{l}0.51 * * * \\
(6.43)\end{array}$ & $\begin{array}{l}0.51 * * * \\
(6.46)\end{array}$ & $\begin{array}{l}0.68^{* * * *} \\
(6.40)\end{array}$ & $\begin{array}{l}0.73 * * * \\
(6.29)\end{array}$ & $\begin{array}{l}0.76^{* * * *} \\
(6.23)\end{array}$ \\
\hline Education & $\begin{array}{c}0.84 \\
(1.23)\end{array}$ & $\begin{array}{c}0.86 \\
(1.27)\end{array}$ & $\begin{array}{c}0.87 \\
(1.29)\end{array}$ & $\begin{array}{c}0.87 \\
(1.29)\end{array}$ & $\begin{array}{c}0.87 \\
(1.29)\end{array}$ \\
\hline Age & $\begin{array}{l}-0.72 * * * \\
(-5.30)\end{array}$ & $\begin{array}{l}-0.70^{* * *} \\
(-5.11)\end{array}$ & $\begin{array}{l}-0.68 * * * \\
(-5.01)\end{array}$ & $\begin{array}{l}-0.68 * * * \\
(-5.01)\end{array}$ & $\begin{array}{l}-0.68^{* * *} \\
(-5.00)\end{array}$ \\
\hline Race & $\begin{array}{c}2.97 \\
(0.54)\end{array}$ & $\begin{array}{c}4.09 \\
(0.73)\end{array}$ & $\begin{array}{c}4.28 \\
(0.78)\end{array}$ & $\begin{array}{c}4.20 \\
(0.76)\end{array}$ & $\begin{array}{c}4.12 \\
(0.75)\end{array}$ \\
\hline Sex & $\begin{array}{c}-7.88^{*} \\
(-1.88)\end{array}$ & $\begin{array}{c}-8.18^{*} \\
(-1.95)\end{array}$ & $\begin{array}{l}-8.31 * * \\
(-1.99)\end{array}$ & $\begin{array}{l}-8.31^{* *} \\
(-2.00)\end{array}$ & $\begin{array}{l}-8.31 * * \\
(-2.00)\end{array}$ \\
\hline Property & $\begin{array}{c}3.07 \\
(0.49)\end{array}$ & $\begin{array}{c}1.60 \\
(0.25)\end{array}$ & $\begin{array}{c}0.73 \\
(0.12)\end{array}$ & $\begin{array}{c}0.64 \\
(0.10)\end{array}$ & $\begin{array}{c}0.61 \\
(0.10)\end{array}$ \\
\hline Urban & $\begin{array}{c}5.74 \\
(1.20)\end{array}$ & $\begin{array}{c}5.22 \\
(1.09)\end{array}$ & $\begin{array}{c}4.67 \\
(0.97)\end{array}$ & $\begin{array}{c}4.57 \\
(0.95)\end{array}$ & $\begin{array}{c}4.51 \\
(0.94)\end{array}$ \\
\hline Know & $\begin{array}{c}0.10 \\
(0.04)\end{array}$ & $\begin{array}{c}-1.01 \\
(-0.42)\end{array}$ & $\begin{array}{c}-1.69 \\
(-0.71)\end{array}$ & $\begin{array}{c}-1.76 \\
(-0.74)\end{array}$ & $\begin{array}{c}-1.79 \\
(-0.75)\end{array}$ \\
\hline Concern & $\begin{array}{l}7.29 * * * \\
(2.72)\end{array}$ & $\begin{array}{l}7.28 * * * \\
(2.73)\end{array}$ & $\begin{array}{l}7.09 * * * \\
(2.67)\end{array}$ & $\begin{array}{l}7.04^{* * * *} \\
(2.65)\end{array}$ & $\begin{array}{l}7.01 * * * \\
(2.64)\end{array}$ \\
\hline Value & $\begin{array}{c}-1.07 \\
(-1.38)\end{array}$ & $\begin{array}{c}-1.20 \\
(-1.54)\end{array}$ & $\begin{array}{c}-1.26 \\
(-1.63)\end{array}$ & $\begin{array}{c}-1.26 \\
(-1.63)\end{array}$ & $\begin{array}{c}-1.26 \\
(-1.64)\end{array}$ \\
\hline Trust & $\begin{array}{c}-0.42 \\
(-0.36)\end{array}$ & $\begin{array}{c}-0.47 \\
(-0.40)\end{array}$ & $\begin{array}{c}-0.52 \\
(-0.45)\end{array}$ & $\begin{array}{c}-0.53 \\
(-0.46)\end{array}$ & $\begin{array}{c}-0.54 \\
(-0.46)\end{array}$ \\
\hline Beliefs & $\begin{array}{l}15.44 * * * \\
(3.30)\end{array}$ & $\begin{array}{l}15.37^{* * *} \\
(3.29)\end{array}$ & $\begin{array}{l}15.52 * * * \\
(3.33)\end{array}$ & $\begin{array}{l}15.57^{* * * *} \\
(3.35)\end{array}$ & $\begin{array}{l}15.60 * * * \\
(3.36)\end{array}$ \\
\hline Activism & $\begin{array}{l}5.71^{* * * *} \\
(5.00)\end{array}$ & $\begin{array}{l}5.83^{* * * *} \\
(5.11)\end{array}$ & $\begin{array}{l}5.88^{* * * *} \\
(5.17)\end{array}$ & $\begin{array}{l}5.88^{* * *} \\
(5.17)\end{array}$ & $\begin{array}{l}5.87^{* * * *} \\
(5.18)\end{array}$ \\
\hline$\sigma$ & $\begin{array}{c}63.92 \\
(36.91)\end{array}$ & $\begin{array}{c}63.74 \\
(36.46)\end{array}$ & $\begin{array}{c}63.47 \\
(35.33)\end{array}$ & $\begin{array}{c}63.41 \\
(35.10)\end{array}$ & $\begin{array}{c}63.36 \\
(34.96)\end{array}$ \\
\hline Log-Likelihood & -2937.9 & -2935.5 & -2930.9 & 2930.0 & 2929.4 \\
\hline
\end{tabular}

a. $t$-statistic in parentheses

$* * *, * *, *$ indicates significance at the $99 \%, 95 \%$, and $90 \%$ confidence levels. 
clude own-price and cross-price variables under different assumptions about the opportunity cost of time. The opportunity cost of time is valued at $0 \%, 33 \%, 60 \%$, and $100 \%$ of the wage rate.

The own-price of the A-P system is of the correct sign and significantly different from zero at the $90 \%$ confidence level when the opportunity cost of time is valued at $0 \%$ of the wage rate. When time is assumed costly, the significance level of the own-price coefficient increases to the $99 \%$ level. The own-price coefficient ranges from -0.52 to -0.17 as the opportunity cost of time increases from $0 \%-100 \%$.

If time is costless the sign of the cross-price coefficient is positive but the coefficient is insignificantly different from zero. When the opportunity cost of time is positive the cross-price effect is positive and significantly different from zero at, at least, the $90 \%$ confidence level.

The explanatory power of the models increases as the relative price variables are added, regardless of time cost assumptions, and increase with the opportunity cost of time. The significance of this result is tested using the likelihood ratio test. For the model with the assumption that the opportunity cost of time is zero, the likelihood ratio test statistic, $\chi^{2}[2]=4.8$, is significant at the $90 \%$ level. When the opportunity cost of time is positive the likelihood ratio test statistic becomes significant at the $99 \%$ level of confidence. For $\delta=.33, \chi^{2}[2]=14$; for $\delta=.60, \chi^{2}[2]=15.8$; and for $\delta=1, \chi^{2}[2]=17$.

The correlation coefficient between income and price variables with no opportunity costs of time are low and not significantly different from zero. With this assumption, as the relative price variables enter the model the income coefficient does not change. When the opportunity cost of time is assumed positive correlation coefficients between relative price variables and income are positive, high, and significantly different from zero. The expected bias in the income coefficient is negative for omission of own-price and positive for omission of the cross-price (Table I). The overall effect is that the coefficient on income increases by $29 \%-40 \%$ with inclusion of relative prices. The measured bias in the income coefficient increases with increases in the assumption about the opportunity cost of time.

\section{Conclusions}

In this paper we investigate specification bias from omission of relative price variables in empirical contingent valuation functions. Omitted variable bias will cause effects of theoretically relevant determinants of WTP to be assumed zero and other coefficients to be biased. Own-price variables will have a negative effect and cross-price variables will have either a positive or negative effect, depending on whether the related natural resource is a substitute or complement, on WTP for quality changes. The expected bias on the income coefficient is negative for own-price variable omission and either positive or negative for cross-price omission when the opportunity cost of time is positive. The expected bias on the own-price coefficient from cross-price variable omission is either positive or negative depending on the relationship between the natural resources and the location of the resources and households.

In the empirical example, inclusion of own-price and cross-price variables significantly increases the explanatory power of the regression equation. The sign of coefficient estimates are theoretically consistent, statistically significant determinants of WTP. Omission of the own-price variable results in a downward biased income coefficient. Omission of the cross-price variable results in upward biased own-price and income coefficients. In a sensitivity analysis, these results hold as long as the opportunity cost of time is valued greater than zero. 
Omission of relative price variables can have important policy implications. When empirical WTP functions are used to forecast future WTP values, the forecast values will be biased. For instance, if income is expected to increase, exclusion of relative price variables could cause WTP forecasts for A-P environmental quality improvements to be downwardly biased. The magnitude of the forecast error will change with changes in assumptions made about the opportunity cost of time. Inclusion of relative price variables in WTP functions will reduce omitted variable bias and reduce WTP forecasting mistakes. Future contingent valuation studies that report estimation results should include the effects of relative prices in empirical valuation functions. ${ }^{12}$

12. Inclusion of measures of relative prices, however, will not always be straightforward or simple. It may be difficult to determine the relevant related natural resources. In this study, we determined that a nearby natural resource with similar characteristics might be related in consumption. We were fortunate in that our expectations were correct. To avoid costly speculation, future contingent valuation surveys might include questions which elicit perceived substitute natural resources from survey respondents. Answers to these questions could guide construction of cross-price variables.

\section{References}

1. Allen, P. Geoffrey, Thomas H. Stevens, and Scott A. Barrett, "The Effects of Variable Omission in the Travel Cost Technique." Land Economics, May 1981, 173-80.

2. Bergstrom, John C., "Concepts and Measures of the Economic Value of Environmental Quality: A Review." Journal of Environmental Management, 1990, 215-28.

3. Bishop, Richard C. and Thomas A. Heberlein. "Does Contingent Valuation Work?" in Valuing Environmental Goods, edited by Ronald G. Cummings, David S. Brookshire, and William D. Schulze. Totowa, N.J.: Rowman and Allenheld, 1986, pp. 123-48.

4. Bockstael, Nancy E., Ivar E. Strand, W. Michael Hanemann, "Time and the Recreational Demand Model." American Journal of Agricultural Economics, May 1987, 293-302.

5. Boyle, Kevin J., Richard C. Bishop, and Michael P. Welsh, "Starting Point Bias in Contingent Valuation Bidding Games." Land Economics, May 1985, 188-94.

6. - Stephen D. Reiling, and Marcia L. Philips, "Species Substitution and Question Sequencing in Contingent Valuation Surveys Evaluating the Hunting of Several Types of Wildlife." Leisure Sciences, April-June 1990. 103-18.

7. Cameron, Trudy Ann, and Daniel D. Huppert, "OLS versus ML Estimation of Non-market Resource Values with Payment Card Interval Data." Journal of Environmental Economics and Management, November 1989, 230-46.

8. Caulkins, Peter P., Richard C. Bishop, and Nicolaas W. Bouwes, "Omitted Cross-Price Variable Biases in the Linear Travel Cost Model: Correcting Common Misperceptions." Land Economics, May 1985, 182-87.

9. Desvousges, William H., V. Kerry Smith, and Ann Fisher, "Option Price Estimates for Water Quality Improvements: A Contingent Valuation Study for the Monongahela River." Journal of Environmental Economics and Management, September 1987, 248-67.

10. Greene, William H. LIMDEP User's Manual. Bellport, N.Y.: Econometric Software, 1990.

11. Halstead, J. M., B. E. Lindsay, and C. M. Brown, "Use of the Tobit Model in Contingent Valuation: Experimental Evidence from the Pemigewasset Wilderness Area." Journal of Environmental Management, 1991, 79-89.

12. Haspel, Abraham E. and F. Reed Johnson, "Multiple Destination Trip Bias in Recreation Benefit Estimation." Land Economics, August 1982, 364-72.

13. Heberlein, Thomas A. "Economics and Social Psychology in Amenity Valuation." in Amenity Resource Valuation: Integrating Economics with Other Disciplines, edited by George L. Peterson, B. L. Driver, and Robin Gregory. State College, Penn.: Venture Publishing, 1986.

14. Hoban, Thomas and William Clifford. Public Attitudes Toward Water Quality and Management Alternatives in the Albemarle-Pamlico Estuarine System. Phase I Report, Project No, 90-27, Albemarle-Pamlico Estuarine Study, N.C. Department of Environment, Health, and Natural Resources, Raleigh, N.C., April 1991.

15. — and - Public Attitudes Toward Water Quality and Management Alternatives in the AlbemarlePamlico Estuarine System. Phase II Report, Project No. 89-6, Albemarle-Pamlico Estuarine Study, N.C. Department of Environment, Health, and Natural Resources, Raleigh, N.C., August 1992.

16. Hoehn, John P. and Alan Randall, "A Satisfactory Benefit-Cost Indicator from Contingent Valuation." Journal of Environmental Economics and Management, September 1987, 226-47.

17. Johnston, J. Econometric Methods. 3rd Edition. New York: McGraw-Hill, 1984. 
18. Judge, George G., William E. Griffiths, R. Carter Hill, Tsoung-Chao Lee. The Theory and Practice of Econometrics. New York: John Wiley and Sons, 1980.

19. McConnell, K. E., "Models for Referendum Data: The Structure of Discrete Choice Models for Contingent Valuation." Journal of Environmental Economics and Management, January 1990, 19-34.

20. — and Ivar Strand, "Measuring the Cost of Time in Recreation Demand Analysis: An Application to Sportfishing." American Journal of Agricultural Economics, February 1981, 153-56.

21. Mitchell, Roben C. and Richard T. Carson. Using Surveys so Value Public Goods: The Contingent Valuation Method. Washington, D.C.: Resources for the Future, 1989.

22. Rosenthal, Donald H., "The Necessity for Substitute Prices in Recreation Demand Analyses." American Journal of Agricultural Economics, November 1987, 828-37.

23. Samples, Karl C. and J. R. Hollyer. "Contingent Valuation of Wildlife Resources in the Presence of Substitutes and Complements," in Economic Valuation of Natural Resources: Issues, Theory, and Application, edited by R. L. Johnson and G. V. Johnson. Boulder, Co.: Westview Press, 1989, pp. 177-92.

24. Silberman, Jonathan, Daniel A. Gerlowski, and Nancy A. Williams, "Estimating Existence Value for Users and Nonusers of New Jersey Beaches." Land Economic's, May 1992, 211-24.

25. Smith, V. Kerry, "Nonuse Values in Eenefit Cost Analysis." Southern Economic Journal, July 1987, 19-26.

26. — , "Nonmarket Valuation of Environmental Resources: An Interpretive Appraisal." Land Economics, August 1993, 1-27.

27. — William H. Desvousges, and Matthew P. McGivney, "The Opportunity Cost of Travel Time in Recreation Demand Models." Land Economics, February 1983, 259-78.

28. Sutherland, Ronald J. and Richard G. Walsh, "Effect of Distance on the Preservation Value of Water Quality." Land Economics, August 1985, 281-91.

29. Whitehead, John C. "Contingent Valuation Technical Analysis," in Public Attitudes Toward Water Quality and Management Alternatives in the Albemarle-Pamlico Estuarine System, Thomas Hoban and William Clifford, Phase II Report, Project No. 89-6, Albemarle-Pamlico Estuarine Study, N.C. Department of Environment, Health, and Natural Resources, Raleigh, N.C., August 1992.

30. - "Ex Ante Willingness to Pay with Supply and Demand Uncertainty: Implications for Valuing a Sea Turtle Protection Program." Applied Economics, September 1992, 981-88.

31. — and Glenn C. Blomquist, "Measuring Contingent Values for Wetlands: Effects of Information About Related Environmental Goods." Water Resources Research, December 1991, 2523-31.

32. - Thomas Hoban and William Clifford. "Measurement Issues with Iterated Continuous/Interval Contingent Valuation Data." Department of Economics, East Carolina University, Greenville, N.C., 1993. 